\title{
Editorial preface to the first volume of Journal of Innovation and Entrepreneurship
}

\author{
Elias G Carayannis ${ }^{1 *}$ and David FJ Campbell ${ }^{2}$
}

\section{Inaugural issue introduction}

In today's world, whether a researcher, policy maker or practitioner, change and turbulence, socio-economic and socio-technical constitute the order of the day and serve to inject substantial amounts of uncertainty and risk that complicate decisions and even endanger their sustainability.

- The Springer Open Access Journal of Innovation and Entrepreneurship (JIE) is meant to look far out enough in time, space and across disciplines and focusing on innovation frontiers, events and processes to engender the formation of unique insights and implications for policy and practice, and in this regard, JIE is to focus on the Geography and History of Innovation and Entrepreneurship.

- We envision the Geography of Innovation and Entrepreneurship as the topological mapping of innovation and entrepreneurship tangibles and intangibles (vs. Geography which maps tangibles).

- We envision the History of Innovation and Entrepreneurship as the chronological listing of innovation and entrepreneurship tangibles and intangibles (vs. History which lists human/social tangibles and intangibles). We will connect, relate and research the relationship, interdependencies and influences of innovation, political regime and development across time and space. We will look into whether innovation and entrepreneurship manifest themselves differently across different sectors and disciplines and how we could identify, analyze, capture and interpret the emerging patterns of innovation on a trans-disciplinary, trans-temporal, and trans-local basis.

- Thus, the value proposition of JIE will be to serve as an enhancing multi-layered, trans-disciplinary lens that allows one to look back in time, across space

\footnotetext{
* Correspondence: caraye@gwu.edu

${ }^{1}$ Department of Information Systems and Technology Management, George Washington University, School of Business, Washington, DC 20052, USA Full list of author information is available at the end of the article
}

and across disciplines clearly enough to be able to envision and anticipate futures with higher confidence and action ability.

- In short, JIE is meant to serve as an uncertainty filtering and risk management device for strategic decision makers in policy and practice alike, as well as students of innovation at large.

- The views presented are meant to be local and recent or regional/global and spanning decades or centuries, and this diversity in calibration and granularity is what has been missing. There is a lot of benchmarking across countries or companies that focuses on the recent and directly relevant. We would like to do more like knowledge, information and data mining across our geographical and historical treasure troves of data, information and knowledge, and across space and time. This would indeed be a trans-disciplinary, cross-sectoral (government, university, industry, civil society) and cross-level (macro, meso, micro) effort.

We are, therefore, in the process of creating a platform and a forum for scholarly research, as well as facilitation of consultation and dialog among government policy makers, industry leaders, academics, NGOs and civil society (implementing the concept of the 'Quadruple Helix of Innovation' and 'Mode 3 Knowledge Production Systems' (Carayannis and Campbell 2005, 2010, 2011) on matters of current critical relevance and significance for Europe as well as the rest of the developed (and developing) world.

The issues at hand are ways and means to understand what are the sustainable and sufficient growth mechanisms for the foreseeable future for developed, knowledge-based economies and societies (such as the Europe and the USA) in the context of multiple, concurrent and inter-connected 'tipping-point' effects with short (MENA) as well as long (China and India) term effects from a geo-strategic, geoeconomic, geo-political and geo-technological set of perspectives (we have recently written about the 'Failed 
Developed States Syndrome', the concept of 'Democratic Capitalism' - as opposed to both 'Jungle and/or Autocratic Capitalism' - and the concept of 'Innovation Diplomacy', leveraging innovation as a source of durable and formidable soft power (Carayannis and Kaloudis 2009; Carayannis and Campbell 2011; Carayannis and Papadopoulos 2011; Carayannis and Campbell 2012).

Europe, in particular, stands at a cross-roads of monumental - in our opinion - challenges as well as opportunities - depending on the leadership competence and staying power, as well as the quality and caliber of their imagination and courage - of all four sectors of the Quadruple Innovation Helix (government, university, industry and civil society) (Carayannis and Campbell 2009) that shapes the continental and global entrepreneurship and innovation ecosystem (Carayannis 2011; Carayannis and Papadopoulos 2011).

This is directly related also to the EU Innovation Union 2020 initiative recently announced, to which the Editor-in-Chief of JIE has repeatedly provided input. In this context, we aspire to make JIE a policy and practice dialog and discovery device - looking beyond the here and now to vistas of empirical evidence and experience that are long and wide enough across time and space that would act as triggers, catalysts and accelerators of structured experimentation and positive change within the context outlined above.

\section{Article summaries}

The articles in this issue focus on the following themes:

In the first article, Carayannis, Thorsten D. Barth and David F. J. Campbell introduce and discuss the Quintuple Helix innovation model (the concept of the Quintuple Helix was published first by the authors Carayannis and Campbell already back in 2010, see Carayannis and Campbell 2010). Quintuple Helix stresses the necessary socio-ecological transition of society and economy in the 21st century; therefore, the Quintuple Helix is ecologically sensitive. Within the framework of the Quintuple Helix innovation model, the natural environments of society and of the economy also should be seen as drivers for knowledge production and innovation by these defining opportunities for the knowledge economy. Quintuple Helix bridges social ecology with innovation. With practical implications of the Quintuple Helix innovation model, the authors then apply to the ecological issue of global warming.

In the second article, Klaus Schuch, George Bonas and Jörn Sonnenburg reflect on main findings of the 'White paper on opportunities and challenges in view of enhancing the EU cooperation with Eastern Europe, Central Asia and South Caucasus in science, research and innovation' (Sonnenburg et al. 2012). They raise the research question, how international cooperation can improve S\&T in the
EECA region. Science diplomacy is being identified as being crucial for driving and further deepening the international $R \& D$ cooperation in the world region that the authors analyze.

Ilavarasan and Parthasarathy refer in their article to the Indian software industry. They discuss whether and to which extent the small software firms in India benefit in growing from linkages with multinationals. Methodically, the authors base the analysis on 172 semi-structured indepth interviews that were carried out in six different software clusters. The authors formulate the proposition that, so far, linkages between small firms and multinationals have not matured to a high degree in India.

Karl Palmås applies in his article the concept of Lazzarato (2007) on 'Strategies of the political entrepreneur' to Noko Jeans, a Sweden-based venture for the production of jeans in North Korea. Can entrepreneurs (political) influence the political regime in a country? The author attempts a reevaluation of the approach by Lazzarato, asserting the usefulness of a concept such as that of the political entrepreneur when analyzing the phenomenon of Noko Jeans.

In the last article of this issue, Stefano De Falco raises the research question, whether it is possible to control or even optimize technology transfer processes. One problem in this context is how to decide on key factors concerning the tolerances for an evaluation of the quality of a technology transfer process. This represents a challenge for managers and IT operators, as well as R\&D experts. For that purpose, the author proposes a distinct model that focuses on and stresses an orientation toward emphasizing solutions.

\section{Author details \\ 1 Department of Information Systems and Technology Management, George Washington University, School of Business, Washington, DC 20052, USA. \\ ${ }^{2}$ Faculty for Interdisciplinary Studies (IFF), Institute of Science Communication and Higher Education Research (WIHO), University of Klagenfurt, \\ Schottenfeldgasse 29 A-1070, Vienna, Austria.}

Received: 14 June 2012 Accepted: 8 August 2012

Published: 8 August 2012

\section{References}

Carayannis, E. G. (2011). The open innovation paradigm and strategic options for EU-US innovation partnerships: the Freie concept in the context of open innovation diplomacy:: . www.euussciencetechnology.eu/ .../CARAYANNIS_BILAT_2011_final\%20(2).pdf. Accessed 4 June 2012

Carayannis, E. G., \& Campbell, D. F. J. (2005). Knowledge creation, diffusion, and use in innovation networks and knowledge clusters: a comparative systems approach across the United States, Europe, and Asia. Connecticut, London: Praeger.

Carayannis, E. G., \& Campbell, D. F. J. (2009). 'Mode 3' and 'Quadruple Helix': toward a 21 st century fractal innovation ecosystem. Int. J. of Technology Management, 46, 201-234

Carayannis, E. G., \& Campbell, D. F. J. (2010). Triple Helix, Quadruple Helix and Quintuple Helix and how do knowledge, innovation and the environment relate to each other?: a proposed framework for a trans-disciplinary analysis of sustainable development and social ecology. International Journal of Social Ecology and Sustainable Development, 1(1), 41-69.

Carayannis, E. G., \& Campbell, D. F. J. (2011). Open innovation diplomacy and a 21st century fractal research, education and innovation (FREIE) ecosystem: building 
on the Quadruple and Quintuple Helix Innovation concepts and the 'Mode 3' knowledge production system. J Knowl Econ, 3, 327-372.

Carayannis, E. G., \& Campbell, D. F. J. (2012). Mode 3 knowledge production in quadruple helix innovation systems: 21st-century democracy, innovation, and entrepreneurship for development. NY, USA: Springer.

Carayannis, E. G., \& Kaloudis, A. (2009). A time for action and a time to lead: democratic capitalism and a new 'new deal' for the US and the World in the twenty-first century. Japan Economic Currents, 71, 6-10.

Carayannis, E. G., \& Papadopoulos, C. B. (2011). The innovation diplomacy concept and the Hellenic-American innovation bridge as a special case-in-point. J Knowl Econ, 2(3), 257-326.

Lazzarato, M. (2007). Strategies of the political entrepreneur. SubStance, 36(1), 87-97. Sonnenburg, J., Bonas, G., \& Schuch, K. (2012). White paper on opportunities and challenges in view of enhancing the EU cooperation with Eastern Europe, Central Asia and South Caucasus in science, research and innovation. INCO-NET EECA Project.: . http://www.increast.eu/_media/White_Paper_on_EUEECA_Cooperation_in_STI_final_April2012.pdf. Accessed 4 June 2012

doi:10.1186/2192-5372-1-1

Cite this article as: Carayannis and Campbell: Editorial preface to the first volume of Journal of Innovation and Entrepreneurship. Journal of Innovation and Entrepreneurship 2012 1:1.

Submit your manuscript to a SpringerOpen ${ }^{\circ}$ journal and benefit from:

- Convenient online submission

- Rigorous peer review

- Immediate publication on acceptance

- Open access: articles freely available online

- High visibility within the field

- Retaining the copyright to your article 